\title{
"MARIA CRIOULA", "JOSÉ PRETINHO" E O "MULATO CLARO DE OLHO DE GATO": REPRESENTAÇÕES DE MESTIÇOS, PRETOS E NEGROS NO SERTÃO BAIANO $(1870-1930)^{*}$
}

Washington Santos Nascimento**

$\mathrm{N}$ este artigo, centro-me na análise das representações construídas sobre a população de descendente de africanos (mestiços, pretos, negros) por diferentes atores do sertão baiano, particularmente do antigo Sertão da Ressaca, atual região de Vitória da Conquista, sudoeste do estado da Bahia, no período compreendido entre os anos de 1870 a 1930 . As fontes que utilizo são, sobretudo, processos crimes e jornais, por se tratarem de documentos que possibilitam adentrar no universo social e cotidiano dos moradores. ${ }^{1}$

Tomo como ponto de partida a teoria das representações sociais, principalmente a partir dos estudos de Pierre Bourdieu, para quem estas são sempre determinadas pelos interesses dos grupos que as forjam. ${ }^{2}$

\footnotetext{
Esse artigo é uma versão modificada do terceiro capítulo da dissertação "Construindo o "negro": lugares, civilidades e festas em Vitória da Conquista/BA" defendida em 2008 no programa de Pós-graduação em Ciências Sociais: Antropologia, da Pontifícia Universidade Católica de São Paulo (PUC-SP), sob a orientação da professora Josildeth Gomes Consorte.

** Doutorando no Programa de Pós-graduação em História Social da Faculdade de Filosofia, Letras e Ciências Humanas da Universidade de São Paulo. E-mail: washingtonprof@gmail.com

As fontes foram coletadas no Arquivo do Fórum João Mangabeira (AFJM) de Vitória da Conquista entre os anos de 2006 e 2008. Alguns documentos estão misturados, por exemplo, encontrei documentos de 1922 em uma caixa de 1924, uma autuação de 1916 em uma caixa de 1890

2 Ver Pierre Bourdieu, A distinção: crítica social do julgamento, Porto Alegre: Editora Zouk, 2007; e Pierre Bourdieu. O poder simbólico. Lisboa: Difel, 2005.
} 
Assim, não são discursos neutros, pois tendem a impor uma determinada visão de mundo, que implica em condutas e escolhas. Segundo Bourdieu, é preciso incluir no real as representações do real, pois "a representação que os indivíduos e os grupos exibem inevitavelmente através de suas práticas e propriedades faz parte integrante de sua realidade social". 3

Procuro, então, enfatizar a função política das representações como sendo a tentativa de legitimação de uma ordem com a sanção de um regime de dominação e a contraposição a essa tentativa pelo grupo "subordinado". Assim, nesse artigo, penso o afrodescendente como um agente político, que, mesmo em uma situação de desigualdade, se manifestava politicamente e criava estratégias diferenciadas para confrontar ou dialogar com o mundo do "branco". ${ }^{4}$

Para entender esses afrodescendentes, uso uma "categoria" criada por Homi Bhabha: a noção de "entre - lugar", ou seja, eles poderiam estar em diferentes "lugares", "posições", às vezes em uma mesma situação, levando assim a criação daquilo que Bhabha chama de populações hifenizadas. Segundo esse mesmo autor, é preciso passar para "além das narrativas de subjetividades originárias e iniciais", ou seja, centrarse nos processos de articulação das diferenças culturais, os "entre-lugares", nos quais é possível perceber a criação de novos signos de identidade e redefinições da própria ideia de sociedade. ${ }^{5}$

Para fins analíticos, separamos esse artigo em três seções diferentes, mas complementares: primeiro as representações sobre mestiços e curandeiros; depois as visões construídas sobre negros por outros igualmente negros; e por fim os olhares dos "brancos" sobre a população descendente de africanos. ${ }^{6}$

\footnotetext{
Ver Bourdieu, A distinção, p. 447

4 Esse mundo "branco" é uma construção ideológica de uma sociedade sertaneja naturalmente mestiça, mas que criava determinados parâmetros comportamentais e de civilidade que deveriam ser, em tese, seguidos por toda a sociedade, é justamente a essa noção de comportamento e civilidade que damos o nome de "mundo branco".

Ver Homi K Bhabha, O local da cultura, Belo Horizonte: Ed. UFMG, 1998, p. 20.

6 A descrição desses personagens como negros e brancos aparece nos processos aqui analisados.
} 


\section{Representando a ambiguidade: olhares sobre mestiços e curandeiros.}

Para discutir sobre os mestiços e as tipologias criadas para representálos, convém lembrar o que diz Josildeth Consorte: "a mestiçagem abriu um leque de possibilidades novas de identificação através das quais foi sendo fragmentado todo o conjunto"; segundo ela os mestiços aqui nascidos, no período colonial, foram sendo distinguidos a partir dos tipos de cruzamentos que representavam, dessa forma surgiram os crioulos, mulatos, cabras, e anos mais tarde, os pardos. ${ }^{7}$ Esses mestiços estavam no "entre - lugar" eram negro-não-negro", "branco-não-branco", ${ }^{8}$ personagens "naturalmente" ambíguos, ${ }^{9}$ assim como eram os curandeiros, temidos e necessários ao mesmo tempo.

Uma das primeiras representações de mestiços aparece, em 1872, em um processo que envolve Maria Bernarda. Moradora da Rua do Espinheiro, na Imperial Vila da Vitória, filha de Marcolina, em 1872, tinha "mais ou menos" 36 anos de idade. Solteira, vivia de seu trabalho e da "porcentagem dos objetos que lhe entregavam para isso". ${ }^{10}$ Que objetos seriam esses? Talvez escravos, já que ela possuía ao menos uma escrava, de nome Felicidade, que estava batendo em uma criança de nome Theotonio, filho de Carolina Teixeira. Diante das "alterações", Rosa Silveira de Oliveira, pede na justiça um Termo de bem viver. Segundo Eduardo Martins, esses termos de bem viver "não diziam respeito às infrações consideradas criminosas, eram essencialmente normatizadores da ordem pública, portanto podia-se fazer prender no caso da reincidência da sua assinatura", ou seja, eram termos "civilizatórios", que visavam garantir a "moral" e os "bons costumes".

\footnotetext{
7 Ver Josildeth Gomes Consorte, "A mestiçagem no Brasil: armadilhas e impasses", Revista Margem, n.10 (1999), p. 109.

8 Parafraseando aqui Eneida A. Reis, Mulato: negro-não-negro elou branco-não-branco, São Paulo: Altana, 2002.

9 Colocamos as aspas no "naturalmente" ambíguo, pois entendemos que a mestiçagem não é sinônimo de ambiguidade natural e que não entendemos a identidade como um fenômeno único e congelado.

10 AFJM, Caixa Diversos 1872 a 1873, Termo de bem viver, 1872

11 Ver Eduardo Martins, Os pobres e os termos de bem viver: novas formas de controle social no Império do Brasil (Dissertação de Mestrado, Universidade Estadual Paulista, 2003) p. 102.
} 
Pela pena do escrivão, Roza assim descreve Maria Bernarda: "Diz Roza Silvana de Oliveira, viúva, e moradora na Rua do Espinheiro desta vila, onde vive de negócios, aí é sua vizinha a crioula Maria Bernarda, prostituta, turbulenta, e habituada a vociferar injurias contra qualquer pessoa". ${ }^{12}$

$\mathrm{Na}$ descrição feita por Rosa, o termo "crioula" aparece antes do nome, para qualificar Maria Bernarda, em seguida, vem uma depreciação da sua condição de mulher, "prostituta", e, logo depois, os qualificativos morais: "turbulenta" e "injuriosa". $\mathrm{O}$ "vociferar injúrias" remete à inexistência de uma linguagem polida. Cor e comportamento moral aparecem associados e marcam a presença do racismo na representação feita. Além disso, existe a ideia de que ela não tinha bons costumes: "turbulenta", "injuriosa" são palavras usadas pela acusação, o que evidencia que o componente racial era mais um argumento pejorativo associado a outros para desqualificar a ré. Analisando São Paulo, entre 1870 e 1920, João Batista Mazzieiro diz que o processo de criminalização e a associação à doença eram constantes nas descrições feitas às prostitutas da época. ${ }^{13}$

O processo não se estende; talvez Rosa quisesse apenas "assustar". No mesmo ano, ela o retira, mas faz questão de ressaltar o que considera um comportamento anti-social de Maria Bernarda: "desistia do processo crime intentado contra a crioula Maria Bernarda e que perdoava as ofensas que por sua turbulência lhe havia rogado a sua constituinte". Aqui, a ideia de que "naturalmente" a ré era "turbulenta", ou seja, novamente a associação entre cor (crioula) e comportamento moral (turbulenta).

Em 1874 temos o processo que envolve o "negro-curandeiro" Joaquim Antônio Bandeira. Dois eixos discursivos, não excludentes, mas complementares, entram na representação de Joaquim, "negro" e "curandeiro"-, mostrando que ele também estava no "entre-lugar", ora negro, ora curandeiro. Ele aparece em um processo por injúrias verbais,

\footnotetext{
2 AFJM, Caixa Diversos 1872 a 1873, Termo de bem viver, 1872.

13 João Batista Mazzieiro, "Sexualidade criminalizada: prostituição, lenocínio e outros delitos São Paulo 1870/1920”. Revista Brasileira de História [online] vol.18, n.35, 1998.
} 
de 1874, impetrado por Severiano da Silva Pinha e sua mulher (acusadores) contra Maximiliano José de Barros e sua mulher, Theofila Boa Sorte (acusados)..$^{14}$

A acusação de Severiano é de que Maximiliano e Theofila estavam difamando sua filha Balbina, por dizerem que ela estava a se envolver de forma "imoral" com Joaquim Antonio Bandeira, um "negrocurandeiro". No primeiro relato, os acusadores ressaltam o papel dele:

Diz Severiano da Pinha Silva, casado com família morador do lugar chamado Olho d'Agua, que achando-se o suplicante ausente de sua casa em fins do mês de junho passado, sua mulher e sua filha Balbina Maria da Silva, menor de 21 anos, foram de visita a casa de Maximiano José de Barros no lugar assim denominado Furados - vizinho desta vila e aí pernoitaram, mas a filha do suplicante nessa noite adoeceu gravemente e achando-se presente um curandeiro de nome Joaquim Antonio Bandeira aplicou-lhe algumas mezinhas, com as quais ela melhorou. ${ }^{15}$

Segundo Severiano, o curandeiro depois de ter bebido cachaça, disse que Balbina estava com "fogo":

e que estava prenhe, depois de ter o mesmo curandeiro uma conversa particular com a mãe da dita, foi esta atacada por uma moléstia desconhecida na história médica. Que sendo Balbina conduzida para o quarto onde dormem os acusados, aí pôs a estrebuchar e ao mesmo tempo abraçando e sendo abraçada pelo curandeiro. Que Balbina, durante o referido ataque pedia a todos, inclusive a mãe, que a deixassem só com o curandeiro e proferia palavras obscenas e impróprias para uma donzela. ${ }^{16}$

$\mathrm{Na}$ fala do acusador, uma "donzela" (menor de 21 anos) teria proferido palavras "obscenas" e "impróprias". Uma "donzela" pura e casta teria sido "corrompida" por um curandeiro. Nesse ponto, também os réus (Maximiliano e Theofila) concordam e dão mais detalhes:

\footnotetext{
14 Esse processo foi localizado por Itamar Aguiar e citado em sua dissertação. Para mais detalhes, ver Itamar Pereira de Aguiar, "As religiões afro-brasileiras em Vitória da Conquista: caminhos da diversidade" (Dissertação de Mestrado, Pontifícia Universidade Católica de São Paulo, 1999), p. 66.

15 AFJM, Caixa Diversos (1874), Processo crime por injúrias verbais, 1874.

16 AFJM, Caixa Diversos (1874), Processo crime por injúrias verbais, 1874.
} 
Que o curandeiro não consentia que pessoa alguma entrasse no quarto onde ele e Balbina estavam; e querendo fazer também retirar a acusada, esta teimou em ficar e não retirou-se, e depois do que pôs a moça a dizer que não podia suportar a luz, e sendo esta apagada pelo curandeiro, a acusada fez de novo acender, isto por duas ou três vezes. Que vendo Balbina e o curandeiro que a acusada não saia do quarto, trataram de sem rebuliço se abraçarem e pedindo o curandeiro um vidro de banha, pos-se a esfregar as partes pudentas de Balbina, consentindo essa e até manifestando prazer chegando mesmo a dizer que o curandeiro fizesse do corpo dela o que quisesse. ${ }^{17}$

O curandeiro teria tocado as partes íntimas da "donzela", o que a teria levado a pedir que fizesse com o seu corpo "o que quisesse". Imoralidade, lascívia e prazer aparecem em destaque na fala dos réus. Continuam os réus a detalhar os atos "imorais" do curandeiro:

Que entre beijos e abraços e tratando-se por meu bem, levaram Balbina e o curandeiro grande parte da noite; e durante este tempo a acusada saiu duas ou três vezes para ir buscar alguma coisa a pedido do curandeiro. Que no dia seguinte Balbina não quis aparecer com a saia que trazia e o curandeiro pediu a acusada uma saia emprestada para a mesma Balbina vestir pelo que a acusada emprestou uma saia cor de rapé. Que Balbina amanheceu com os beiços inchados e a cútis rosada. ${ }^{18}$

Na citação, várias expressões demonstram uma suposta "lascívia" e "imoralidade" da moça e do curandeiro, tais como: "beijos e abraços", "se tratando por meu bem", "não quis aparecer com a saia que trazia" (manchada de sangue diante da perda de virgindade da donzela?) e "beiços inchados".

Segundo os réus, a mãe de Balbina parece que sabia o que estava acontecendo, mas confiava na "honra" que o curandeiro poderia oferecer a sua filha:

Que Balbina mandou que o curandeiro deitasse na cama com ela, e opondo-se a isso a acusada, a mãe de Balbina, que tudo ouvira de fora, disse

\footnotetext{
17 AFJM, Caixa Diversos (1874), Processo Crime por injúrias verbais, 1874.

18 AFJM, Caixa Diversos (1874), Processo Crime por injúrias verbais, 1874. 
à acusada que nenhum mal faria e que o curandeiro tinha honra para dar a sua filha e à acusada". ${ }^{19}$

Já as impressões dos acusadores sobre o curandeiro são diferentes: "Que os pais de Balbina são os primeiros a difamarem-na, consentindo que andasse em passeios na garupa de um biltre como o negro curandeiro". ${ }^{20}$ No momento em que associam o curandeiro a uma imagem negativa, a sua cor é logo posta em evidência. "Negro" e "biltre" (vil, patife...), cor e comportamento associados.

Não tendo como escapar do fato de que sua filha teria tido um "relacionamento" com o curandeiro, a mãe o justifica como movido por forças sobrenaturais, ou seja, por um feitiço do curandeiro. Dessa forma, tanto na visão da defesa quanto na acusação, o curandeiro é o responsável pela corrupção dos costumes,

Que os acusados guardavam silêncio de tais ocorrências por serem muito vergonhosas até que foram descobertas pela própria mãe de Balbina, que narrando os fatos, dizia que tudo tinha-se dado por feitiço da acusada. Que se houve feitiço, o feiticeiro é o curandeiro. ${ }^{21}$

João Moreira Prates, empregado público, testemunha do caso, reforça a ideia de que o curandeiro era "imoral" e oferece detalhes sobre os acontecimentos, particularmente sobre o seu comportamento:

[...] em certa hora depois de beberem muita cachaça, sentando-se o dito curandeiro Bandeira junto a Balbina, e espreguiçando-se junto dela, esta também fizera o mesmo, isto indicando sensualidade, e que dali foram para o quarto onde dormem Maximiano e sua mulher, e indo também o curandeiro, este não queria que pessoa alguma entrasse no dito quarto ficando no mesmo a força a mulher de Maximiano e vendo sem vestido a dita Balbina, o curandeiro deu a esta um pedaço de ananaz dizendo que era para ela não mover o seu filho e depois de esfregar a barriga de Balbina e mais outros lugares com a banha, apagou a luz, porem a mulher de Maximiano fez acender de novo, e isto por algumas vezes e

\footnotetext{
19 AFJM, Caixa Diversos (1874), Processo Crime por injúrias verbais, 1874.

20 AFJM, Caixa Diversos (1874), Processo Crime por injúrias verbais, 1874.

21 AFJM, Caixa Diversos (1874), Processo Crime por injúrias verbais, 1874.
} 
pondo-se Balbina a dizer — recebo a vós senhô. O curandeiro dissera discunjura de sinhô que aqui está doutô. ${ }^{22}$

A imoralidade é associada ao consumo de cachaça, que teria levado a atos que remetem à sensualidade. ${ }^{23} \mathrm{~A}$ mesma testemunha continua relatando os feitos imorais do curandeiro e a referência às suas divindades:

[...] estando Balbina deitada adiante da mulher de Maximiano e supondo o curandeiro estar já noite avançada que esta estava já dormindo, o mesmo curandeiro foi devagar deitar-se na cama e abriu com jeito as pernas de Balbina, que nelas se acomodava, e que sendo visto pela mulher de Maximiano esta lhe dera um empurrão que o fez cair no chão e ouvindo Maximiano que estava na tenda tal barulho viera a porta do quarto e perguntara a sua mulher o que era aquilo e antes de sua mulher responder o dito curandeiro pedira a esta que pelo Senhor Bom Jesus da Lapa nada dissesse, pelo que a mulher respondeu a seu marido que não era nada. ${ }^{24}$

"Imoral", o curandeiro fora lentamente deitar-se na cama e, com "jeito", abriu as pernas de Balbina. O grau máximo de imoralidade tinha sido alcançado. Ao ser descoberto, ele invoca então um santo católico, Bom Jesus da Lapa. ${ }^{25} \mathrm{O}$ processo termina com o despacho do juiz

22 AFJM, Caixa Diversos (1874), Processo crime por injúrias verbais, 1874.

23 Parece-me que Balbina tinha recebido santo, quando ela disse "Recebo a vós senhô" e o curandeiro pediu que a entidade saísse, "O curandeiro dissera discunjura de sinhô que aqui está doutô". O que seria esse conjuro? Analisando o México Colonial, Serge Gruzinski diz que o conjuro era uma forte idolatria entre a população indígena, que, por meio dela, chegava até o outro plano. Segundo ele "é mais um poder sobre os seres e as coisas do que um saber, é uma práxis, um estabelecimento de relações, mais do que uma especulação intelectual. O que não significa que a exclua completamente: curandeiros e outros poderem ter sido levados a pensar o conjunto dos conjuros que conheciam, mas este não era seu objetivo imediato e habitual". Continua ele que o conjurador é aquele que recebe por um período de tempo a energia divina, como fazem os homens deuses pré-hispânicos; ele é a encarnação do próprio deus e poderia manipular como bem quisesse uma determinada situação, mesmo que não fosse fácil transmitir por meio de palavras o mundo criado pelas invocações. Quanto aos medicamentos utilizados pelo curandeiro, existe o uso de elementos do universo medicinal indígena, como o ananás e a banha. A utilização de óleos e/ou banhas constitui-se numa prática comum entre os curandeiros/feiticeiros do Brasil Colônia. Laura de Mello e Souza descreve vários exemplos de utilização de untos de carneiros (sebo), banhas e diferentes tipos de óleos. Para mais informações, ver Serge Gruzinski, A colonização do imaginário, São Paulo: Companhia das Letras, 2003; e Laura de Mello e Souza, O diabo e a Terra de Santa Cruz. Feitiçaria e religiosidade popular no Brasil Colonia, São Paulo: Companhia das Letras, 1986.

24 AFJM, Caixa Diversos (1874), Processo crime por injúrias verbais, 1874.

25 Analisando as religiões afro-brasileiras em Vitória da Conquista (1930 a 1999), Itamar Aguiar nos diz que, nessa cidade, em algumas casas a entidade do caboclo aboiador foi sincretizada com Bom 
sobre a improcedência da denúncia por injúrias verbais impetrado por Severiano e o condena a pagar a custa do processo. Severiano recorre, mas perde novamente na segunda instância. As "imoralidades" cometidas tanto pelo curandeiro quanto pela filha de Severiano, Balbina, ficaram então provadas. A tese de que Balbina agira sob um feitiço do curandeiro não convencera.

No processo, vemos uma busca pelo lugar do curandeiro; mas, por ele ser "negro" e "curandeiro", sua caracterização era ambivalente e incerta, porém, de qualquer maneira, o "lugar", onde parte dos personagens envolvidos acreditavam que ele estava, era o lugar da "imoralidade" e nesse sentido o fato de ser "negro" e "curandeiro" reforçava essa tese.

Outro processo que destaca um suposto "feiticeiro" é de 1876 e envolve Elias Aneceto de Santana, tido por testemunhas como um homem valente, "que o réu, em um só dia espancara três [...] que prometeu não sair desta vila enquanto não tirar a vida de um". ${ }^{26}$

Segundo essas mesmas testemunhas, Elias se definia como "negro velho da Bahia" e fazia questão de propalar isto pelas ruas da Imperial Vila da Vitória. Tomando como verdadeira essa informação, em sua autoimagem transparece a cor de sua pele e sua origem, no caso específico, a cidade de Salvador. Elias lida com dois temores existentes na vila: o de ser negro e de ser forasteiro. A imperial Vila da Vitória por ser uma cidade no cruzamento de uma rede viária que ligava o Alto Sertão Baiano com o litoral Sul e o recôncavo e Salvador com Minas Gerais, era espaço de circulação de diferentes forasteiros, o que proporcionava "certo costume" com forasteiros, mas, mesmo assim, estes ainda causavam temor nos moradores locais. Além do mais, Elias não era um forasteiro qualquer, quem sabe até mesmo, como diz o documento, um negro "feiticeiro de Salvador". Tal qual o curandeiro Joaquim Bandeira, era um personagem multifacetado, negro-feiticeiro-da Bahia, estava também no entre-lugar.

Jesus da Lapa e em outras com Oxalá. Segundo John Thornton, dos elementos culturais de matriz africana, indubitavelmente as religiões foram aquelas que alcançaram um grau maior de mutabilidade nas Américas. Para mais informações, ver Pereira de Aguiar, "As religiões afrobrasileiras em Vitória da Conquista", p. 110 e 132; John Thonrnton, A África e os africanos na formação do mundo atlântico, Rio de Janeiro: Elsevier, 2004.

26 AFJM, Caixa Diversos, 1875 - 1879, Apelação crime - 1876. 
Em 1888, na descrição daqueles chamados de "mulatos", a cor aparece também como um determinante comportamental, mas de maneira mais específica, associada à criminalidade. Em um processo cível de 1888, o negociante Deraldo Pereira, de 44 anos, assim relata o assalto que sofrera:

[...] inocente e pacificamente passeava em sua calçada, no dia vinte do corrente às quatro horas da tarde, quando foi assaltado por um mulato chamado Cândido que vive na companhia de Ancelmo da Silva Brasileiro, o qual mulato pelas costas dele respondente abraçou-o de forma tal que impossibilitou-o de qualquer movimento, neste ínterim apareceu Ancelmo da Silva Brasileiro, o escravo Estevam, do domínio de Dona Lydia Roza Guedes, e Onésimo da Silva Brasileiro, de idade de mais ou menos dezesseis anos. ${ }^{27}$

Na narrativa do depoente, o discurso se desenvolve suave -- "inocente e pacificamente passeava" - para, depois, explodir: "quando depois foi assaltado por um mulato". Mulato foi quem o assaltou, só depois é que aparece o nome, Cândido, e reitera: "o mulato". ${ }^{28}$

Em um processo cível de 1889, encontrei a descrição de um exescravo chamado Inocêncio. No processo, em algumas representações, construídas principalmente pelo seu ex-tutor, a questão da cor logo aparece: "Inocêncio crioulo". O "crioulo" funciona como um qualificativo descritivo do acusado.

No registro de batismo de Inocêncio, feito em 1873, o vigário José Moniz Cabral Leal de Menezes descreve-o sucintamente: "Inocêncio, livre, crioulo" - nome, condição e cor, indissociavelmente ligados. Onze anos mais tarde, em 1884, já sob a tutela de Luiz Moreira dos Santos, Inocêncio é retratado pelo tutor como alguém que "não quis mais sujeitar-se a trabalhar no serviço do hoje ex-tutor, e isso porque já estava possuído da influência de casar-se, o que realizou pouco tempo depois". ${ }^{29}$ Expressões fortes, como "sujeitar-se", "possuído", são utilizadas na representação das atitudes de Inocêncio. Segundo o tutor, para impedir que Inocêncio se cassasse, seria preciso prendê-lo. Entretanto, "com a realização do qual talvez fosse este espancado por soldados,

27 AFJM, Caixa Diversos 1890 a 1899 (22), Auto de corpo de delito, 1888

28 No ultimo ano da escravidão se vê "mulatos" livres e escravos juntos.

29 AFJM, Caixa Diversos 1888 a 1890, Termo de Tutela, 1889. 
conforme o abusivo costume que há nesse termo". ${ }^{30}$ Luiz Moreira dos Santos apresenta-se como alguém que poderia defender Inocêncio da violência contra os presos e/ou descendentes de africanos. ${ }^{31}$

Morto em 1897, Inocêncio é novamente retratado pelo vigário, agora, com o nome completo, "Inocêncio Minas dos Santos", possivelmente o "minas" do sobrenome seja uma derivação do termo "Mina", presente no sobrenome de seu pai, Joaquim Mina, e o "dos Santos", seja advindo de seu tutor Luiz Moreira dos Santos. Em seu sobrenome, então, a sua procedência, "Mina", e a sua ligação posterior "dos Santos". "Cor/procedência" (Mina) e "condição" (ligado à família dos Santos) continuam aparecendo na descrição de Inocêncio.

Ao final do processo, percebo que antes da Abolição há um Inocêncio "crioulo", "livre", "menor", "sem domicílio", "sem ocupação"; já depois da Abolição: descendente de escravo ("Minas"), que não queria "sujeitar-se" mais, estando "possuído" para casar-se. Se antes era "livre", "mas sem domicílio", "nem ocupação", tinha que se sujeitar. Agora livre, mas na iminência de se casar, não queria submeter-se mais. Entretanto estava suscetível a violências (cadeia). Comum aos dois momentos é a associação direta à ancestralidade escrava de Inocêncio.

Continuando a análise das representações de mestiços em processos crimes, localizei um processo do início do século XX, de 1919, em que um ofendido descreve seus ofensores com uma alusão a "mulato" como um dos eixos explicativos: "que um de seus agressores é baixo, mulato e que tem dois dentes de ouro, sabendo quanto ao outro que é alto da mesma cor". ${ }^{32}$ Nos dois casos um atributo físico, a altura (baixa), aparece associada à cor (mulato).

Em outro processo de 1922, há uma descrição de Ana Maria dos Reis, nos autos de corpo de delito, feita pelos "doutores" Crescêncio Antunes da Silveira e o cirurgião-dentista Amphilóphio Pedral Sampaio. Ana é descrita como "surda e dislálica, parda, de cabelos bons" ${ }^{33} \mathrm{Na}$

\footnotetext{
30 AFJM, Caixa Diversos 1888 a 1890, Termo de tutela, 1889.

31 Em alguns documentos, a cadeia é associada a uma senzala, é o que se percebe em ofícios enviados nos anos de 1871 e 1872 para o presidente da província.

32 AFJM, Caixa Diversos 1919, Sumário de culpa, 1919.

33 AFJM, Caixa Diversos 1919, Sumário de culpa, 1919.
} 
descrição "técnica", a condição de saúde aparece antes, para só depois, enfocar a questão da cor, "parda". A expressão "de cabelos bons" parece uma tentativa de aproximar a parda do mundo branco.

Anos depois, em 1924, outra menção a "mulato" aparece na descrição do escrivão de polícia, quando diz que: "no dia 14 do corrente mês, foi assassinado Antônio de Tal de cor mulato claro, olho de gato". Nessa descrição, "mulato claro" com "olho de gato" chama a atenção a matiz de mestiçagem de Antônio. A imagem construída no processo é a de alguém que "procedia mal", um "grande turbulento", segundo uma testemunha:

o procedimento era péssimo, tanto que a [sic] poucos dias tinha chegado de Itabuna com duas cutiladas no braço, em barulho de facão que ali provocou, por tanto não deixaria de ser um grande turbulento, e tinha por costume viver provocando a este e a aquele, tanto que esteve preso nas cadeias desta cidade por duas vezes. ${ }^{34}$

A imagem de turbulência é associada ao comportamento de "viver provocando a este e a aquele". O processo se estende por dez anos e, nele, duas imagens de Antônio estão sempre presentes: na descrição do escrivão e do promotor, a questão da cor, "o mulato"; já na descrição das testemunhas (seis no total, todos lavradores e casados), Antônio aparece como "turbulento". ${ }^{35}$ A estratégia era caracterizá-lo como alguém violento, e o acusado, como alguém que agira em legítima defesa.

O que a análise da documentação nos permite dizer é que o racismo e a ancestralidade escrava eram presentes na representação desses personagens, feita, sobretudo por aqueles que detinham o poder na localidade, entretanto, a distinção social também se fazia presente. Mas essas representações nunca apareciam sozinhas, estavam associadas também a uma falta de "civilidade" desses personagens e que chegava a atos condenáveis de imoralidade, como no caso do negro-curandeiro.

Outra questão importante a ser ressaltada é a distinção que a população de Vitória da Conquista fazia entre crioulo, pardo, mulato, cabra e pre-

\footnotetext{
34 AFJM, Caixa Diversos 1924, Sumário de Culpa, 1924.

35 A presença do termo "turbulento", nos diferentes depoimentos, talvez se deva à normatização imposta pela pena do escrivão, como se pode depreender do caso de Maria Bernarda (1872) anteriormente analisado.
} 
to, o que revela a existência da noção da intensa miscigenação formadora daquele grupo populacional. Essas denominações, embora não se refiram diretamente às condições de vida daquela população de cor, evidenciam a existência de outros níveis de diferenciação social que passavam ao largo das distinções de livres, forros e escravos e mostram certa "mobilidade" no que se refere aos "lugares" em que estavam esses personagens.

\section{Negros representando negros: lugares e ambivalências}

Um dos processos em que fica visível a representação de negros feita por outros igualmente negros é de 1875 , e envolve a história de duas famílias afrodescendentes, a de Antônio Latão e a de Benedito Soares. Antônio Latão, descendente de africanos, era casado com Umbelina, negra, ventre-livre, com quem tivera ao menos uma filha, Maria. Já Benedito, negro, era casado com Joana (sem identificação) e tinha um dos filhos chamado Gabriel. Todos eram moradores do Arraial dos Poções, então pertencente à Imperial Vila da Vitória e eram de famílias inimigas havia muito tempo. Não está claro no processo o início da contenda, mas ela ganhou proporções judiciais quando foi lançado nas ruas de Poções um pequeno "pasquim" em forma de cordel, onde Maria, viúva de Deolino, filha de Antônio Latão é acusada, por Gabriel, filho de Benedito, de roubar, juntamente com a escrava Sofia, a casa comercial de Raimundo Pereira de Magalhães, onde trabalhavam.

O autor inicia a sua descrição de Maria com a "sugestão" de que, depois da morte do marido, ela estava se comportando de maneira diferente:

Senhores eu estou pronto

Venham prestar atenção

Um causo que aconteceu

Com Maria de Latão

Senhores dão licença

Que quero explicar

Depois que Deolino morreu

Olha Maria como está. ${ }^{36}$

\footnotetext{
${ }_{36}$ AFJM, Caixa Diversos 1875 a 1879, Apelação crime, 1875.
} 
Para quem não conhecia Maria, ou não se lembrava dela, ele faz questão de lembrar quem era e onde morava:

Muito dos senhores

Não conhece Maria

Mora na rua de baixo

Bem na beira do caminho. ${ }^{37}$

Maria morava na rua de "baixo", enquanto ele, Gabriel, morava na rua de "cima". Mas quem definia o que era alto ("cima") e baixo? Talvez houvesse, na diferenciação das ruas, uma gradação social e de cor. Depois de ter identificado Maria e a forma como estava agindo, "diferente" ("olha Maria como está"), o autor a acusa de estar roubando um dos maiores comerciantes do Arraial dos Poções, Raimundo Pereira Magalhães:

O pai na rua de cima

Olhando para o padrim

A filha na rua de baixo

Roubando o Raimundim. ${ }^{38}$

Depois de acusar Maria de ser ladra, Gabriel a compara à mãe, Umbelina (negra/mestiça) que, também, segundo Gabriel, era "torta". Já Latão (negro/mestiço), pai de Maria, era "cego":

Torta como Umbelina

Nem tão cego como Latão

Nem tão ladra como Maria

Que furta até no balcão. ${ }^{39}$

Enquanto Latão era tido como "cego", a ex-escrava Umbelina era "torta", Maria era "falsa", sorrateira, perspicaz. Por que Latão era cego? Por que não via a filha roubar e/ou por ter se casado com a "torta" Umbelina?

\footnotetext{
AFJM, Caixa Diversos 1875 a 1879, Apelação crime, 1875

38 AFJM, Caixa Diversos 1875 a 1879, Apelação crime, 1875.

39 AFJM, Caixa Diversos 1875 a 1879, Apelação crime, 1875.
} 
A Maria de doze anáguas

Bastante serpentina

Latão tão bem pinta

Negocio bem a surdina. ${ }^{40}$

E principalmente "ladra", que roubou Raimundo em trinta mil réis. O roubo é descrito de maneira alongada, especialmente a tentativa de Raimundo e sua mulher de descobrirem quem era o ladrão:

Maria de doze anáguas

Para influencia do Mundo

Mais quem estava sofrendo

Era a casa de Raimundo

Logo naquele dia

Latão foi delegado

Raimundo tomou de Maria

Trinta mil réis furtado

Este é o que me consta

Quando foi o que ele tomou

Julgava ser gente da casa

E Maria foi quem furtou

Raimundo não sabia

Do roubo que ele sofria

[...]

Dele vender a nêga Sufia

A mulher se apegou

Com os santos de sua devoção

Que ele lhe mostrasse

Quem era este ladrão

Falou esta palavra

Com dor no coração

De mandar dizer uma missa

E o ver com os pés no chão. ${ }^{41}$

40 AFJM, Caixa Diversos 1875 a 1879, Apelação crime, 1875.

${ }^{41}$ AFJM, Caixa Diversos 1875 a 1879, Apelação crime, 1875. 
Depois da "intercessão" dos santos, eis então que a "ladra" é descoberta:

Logo no outro dia

Em cima do balcão

Raimundo chamou Maria ${ }^{42}$

Venha ver o ladrão

Ficou ela muito contente

Em com bastante alegria

Perguntando quem era o ladrão

Ele disse que era Maria ${ }^{43}$

Ela se desanimou

Não me diga isso não

A Maria que furtou

Foi Maria de Latão. ${ }^{44}$

Depois da descoberta de Maria como suposta ladra, Gabriel agora ataca o pai, Latão, que, segundo ele, dizia que os outros eram "ladrões" e que ele, Latão, também queria ser um cidadão. Posso supor, ao menos, que aí havia certa ironia pelo fato de um negro, liberto, morador da rua "de cima", querer ser cidadão.

Latão disse que não vinha

Mais nesta rua de cima

Porque cá só tinha ladrão

E porção de assassinos.

Como ele agora está

Querendo ser cidadão

Falando da rua de cima

E lá mesmo é que tem ladrão. ${ }^{45}$

Nesse momento, mais uma vez entra em cena outro personagem que tinha sido citado anteriormente. Trata-se de Sofia, escrava de Raimundo Pereira Magalhães, "negra" e que trabalhava ao lado de Maria.

\footnotetext{
42 A esposa de Raimundo Pereira Magalhães.

43 A filha de Latão.

44 AFJM, Caixa Diversos 1875 a 1879, Apelação crime, 1875.

45 AFJM, Caixa Diversos 1875 a 1879, Apelação crime, 1875.
} 
No cordel, também o relato dos maus-tratos que essa escrava sofrera para denunciar Maria:

Raimundo mais que depressa

Amarra a negra Sofia

Indo com ela na corda

Ela bateu na porta de Maria

Raimundo na ponta da corda

Vendo o que a negra dizia

Ela bateu na porta

Mim dá o dinheiro Maria. ${ }^{46}$

Vemos uma escrava amarrada, andando pelas ruas de Poções, puxada pelo senhor pela ponta da corda e, também, a associação entre escravo e negro. Ao relatar o momento em que a escrava delata Maria, Gabriel diz: "Vendo o que a negra dizia". Dessa forma, com a ajuda da "negra" escrava, Maria é "descoberta" e entrega o dinheiro. O autor do cordel manifesta então o seu contentamento com o fato de Maria ser chamada de ladra.

Raimundo foi enxergando

Com muita alegria

Maria foi intregando

Todo o dinheiro que tinha

Ele foi arrecebendo

O dinheiro com as mão

Foi logo dizendo

Já sei quem é o ladrão

Alegre que ele ficou

Prejuízo que sofria

Disse ela em voz baixa

Você é uma ladra Maria. ${ }^{47}$

A escrava Sofia disse em "voz baixa" que Maria era a ladra. Duas

${ }_{46}$ AFJM, Caixa Diversos 1875 a 1879, Apelação crime, 1875.

${ }^{47}$ AFJM, Caixa Diversos 1875 a 1879, Apelação crime, 1875. 
possibilidades complementares (ou não) podem conter essa situação: a primeira é o que a escrava estivesse sendo torturada; e a segunda é que fosse cúmplice de Maria. Segundo o autor do cordel, tanto a escrava Sofia como Maria estavam roubando Raimundo Pereira Magalhães:

Ele chamou Latão

Assim que amanheceu o dia

Que estava roubado

Por Sofia e Maria. ${ }^{48}$

A partir daí, vemos que houve uma disputa com envolvimento de outros personagens sobre o fato de Maria ter sido ou não ladra, tais como João Chaves, Felisberto, Puluca e Juca, o que evidencia a amplitude que teve o fato na sociedade do Arraial dos Poções. ${ }^{49} \mathrm{Na}$ fala do autor do cordel, o caráter racializado da escrava, "a negra", contrapõe-se à Maria, chamada apenas pelo nome. A questão provavelmente não seja apenas de “cor", mas, de ser escrava: Sofia era escrava e Maria não o era.

Raimundo estava falando

João Chaves disse que não

A negra tinha ido ver

Era um par de butão

A negra bateu na porta

Isto é muito certo

Maria de quem é os butão

São de Felisberto.

Raimundo disse mesmo

Que ainda tinha redevu

Que tem uma nopretissa (?)

E lá tem uns baús

O Latão com estas fala

Foi ficando cheio de angustia

Raimundo falou com Puluca

[...] mandado de busca

\footnotetext{
48 AFJM, Caixa Diversos 1875 a 1879, Apelação crime, 1875.

49 Mesmo porque era um Arraial pequeno e o maior comerciante local supostamente estava sendo lesado.
} 


\section{$[\ldots]$}

Por influência do mundo

Arretirou os baús

Franqeou a casa Raimundo

Raimundo requer busca

Pois falou com Puluca

Diga a Latão e a Maria

Que o ladrão e a mulher de Juca

Foi logo naqueles dias

Que veio [...] João

Quando faltava qualquer coisa

Raimundo chamava Latão. ${ }^{50}$

Após a participação desses diferentes personagens no debate sobre o envolvimento ou não de Maria no roubo, inclusive da autoridade policial local, "Puluca", Latão é chamado à cena, e Raimundo the revela que Maria teria sido a responsável pelo roubo:

Venha cá Latão

Venha ver o que me faltou

Olha que tudo isto

E Maria que furtou ${ }^{51}$

Ao saber disso, Latão ficou estupefato, o que fez com que Gabriel o tratasse de maneira jocosa, pois ficara com "a cara no chão", o que revela certo prazer de Gabriel em descrever a cena:

Latão baixava a cabeça

Com a cara no chão

É bem feito para o torto

Chame agora os outros ladrão. ${ }^{52}$

Mas as impressões dele não são somente sobre Latão, mas também sobre João Chaves, que anteriormente tinha protegido Maria. Isso se dera, segundo o "cordelista", porque suas filhas teriam recebido presentes de Maria, mais especificamente vinte mil réis.

\footnotetext{
50 AFJM, Caixa Diversos 1875 a 1879, Apelação crime, 1875 .

51 AFJM, Caixa Diversos 1875 a 1879, Apelação crime, 1875.

52 AFJM, Caixa Diversos 1875 a 1879, Apelação crime, 1875.
} 
No dia que João Chaves

Casou as duas filhas

Maria deu vinte mil reis

Para comprar duas novilhas. ${ }^{53}$

Novamente a fala se volta contra Latão, que "gostava de falar dos outros", mas que, agora, se via numa situação em que sua filha era acusada de ser uma ladra:

Latão para falar dos outros

Juro que infara

Mais ninguém cuspa para cima

Que não lhe caia na cara. ${ }^{54}$

Agora se volta contra Maria e sua "desfaçatez" e destaca o fato de que não se pode confiar em todo mundo:

Amancio bate sentido

Não se fie em todo mundo

Olha Maria que não te faça

O que ela fez a Raimundo. ${ }^{55}$

No final, ele deixa entender que estava prevendo que Maria se incomodaria com o conteúdo e impressões contidas em seu cordel,

Já me despeço

A Deus que me arrretiro

Até quando cá tornar

Será breve a minha vinda

Se Maria não se incomodar. ${ }^{56}$

Gabriel termina, a meu ver, fazendo uma nova alusão a Latão, que vivia acusando os outros, mas que não se dava conta das coisas que estavam acontecendo debaixo de seus olhos:

\footnotetext{
53 AFJM, Caixa Diversos 1875 a 1879, Apelação crime, 1875.

54 AFJM, Caixa Diversos 1875 a 1879, Apelação crime, 1875.

55 AFJM, Caixa Diversos 1875 a 1879, Apelação crime, 1875.

56 AFJM, Caixa Diversos 1875 a 1879, Apelação crime, 1875.
} 
Voz do povo

Quem não quer ser pele

Não vista o lobo. ${ }^{57}$

Apesar de ter sido escrito para relatar o roubo que, supostamente, Maria teria cometido no estabelecimento comercial de Raimundo Pereira Magalhães, grande parte das representações construídas no cordel são de Antonio Latão. Um "negro", que se casara com a ventre-livre Umbelina, morador da rua "de cima", e que, segundo Gabriel, "queria ser cidadão", dizendo que "os outros eram ladrões", mas sua filha era quem estava roubando.

Convém discutir o que era um negro ser "cidadão" em 1875, provavelmente havia todo um processo de "acomodação" da população negra com o crescimento de alforrias e da formação de famílias negras, que antecedeu a própria Abolição de 1888 e que dizia respeito, entre outras coisas, à concessão, ainda que extremamente precária, de algum tipo de cidadania para esses ex-escravos.

Outros traços da presença negra também são relatados, como os maus-tratos contra a escrava Sofia, que fora amarrada com uma corda e assim andou por todo o Arraial dos Poções até a casa de Maria, com o "senhor" na ponta da corda. Torturada, Sofia revelara que era uma das ladras, ao lado de Maria.

Nesse caso, não posso também deixar de destacar o fato de que uma escrava e uma livre, ambas descendentes de africanos, trabalhavam lado a lado no balcão de um estabelecimento comercial e, segundo o autor do cordel, também estavam juntas no roubo a Raimundo Pereira Magalhães.

Quando esse cordel começou a circular no Arraial dos Poções, Maria, enquanto tomava banho na lagoa com Ana de Jesus, fala mal de Gabriel, filho de Benedito, que escrevera o cordel. Outro filho de Benedito, Joaquim, ouve a notícia e conta ao pai, que vai à lagoa com um chicote na mão e xinga Maria de "puta, besta, vaca e ladra" e, segundo umas das testemunhas, "ameaçava na face do rosto com uma taca (chi-

\footnotetext{
${ }_{57}$ AFJM, Caixa Diversos 1875 a 1879, Apelação crime, 1875.
} 
cote)". Diante da tentativa de agressão, Maria recua e diz que não estava contra ele, o que não o impede de continuar seus xingamentos. Todos eles são comportamentais, senão vejamos: "puta", o seu comportamento de mulher; "besta", "vaca" a sua animalidade ou falta de educação/inteligência; e "ladra", a sua atitude moral.

Vendo a alteração, a mãe de Maria, Umbelina, intervém em defesa da filha e diz que Benedito deveria provar que sua filha era ladra. Benedito então lhe responde que, havia poucos dias, Raimundo Pereira de Magalhães e seus escravos the tinham dito isso. ${ }^{58}$ Umbelina então contesta e diz que ladrões eram Benedito e os escravos de Raimundo. Diante da ofensa, Benedito responde: "cala a boca negra se não te meto o chicote" e xinga-a de "negra, cativa, besta e puta".

No xingamento, o uso dos adjetivos "negra e cativa" juntos evidencia que nem todos os negros vieram do cativeiro; o termo "besta" sugere animalidade, aquele que não enxerga nada, que usa viseira, e "puta", tal qual no caso de Maria, constitui-se uma difamação à condição de mulher.

Mesmo sendo "negro", como atestam as testemunhas e o próprio processo, Benedito demarca uma clara fronteira entre ele e Umbelina: ela era negra, e ele, não. E para provar isso, se preciso fosse, "daria de chicote" em Umbelina, como assim também faziam os antigos senhores de escravos. A construção de uma fronteira está clara quando ele diz que "encontrando-se com a mulher do autor na beira do rio, muito distante da casa, e recebendo da mesma mulher alguns insultos, apenas respondia-lhe com estas palavras: não quero alterações com negra". ${ }^{99}$

Em um contexto marcado por intensos preconceitos, ao proferir: "não quero alterações com negra", ele procura dizer de que lado queria estar. Em sua defesa, a cisão racial presente naquela sociedade aflora, e ele tenta construir uma auto-imagem pautada na negação do mundo negro.

No processo ele afirma que "a palavra negra não tem acepção injuriosa, ainda mesmo falando-se de pessoa que nasceu de ventre li-

\footnotetext{
${ }^{58}$ Interessante destacar que Benedito coloca em condição de igualdade, no que se refere à autenticidade da informação Raimundo Magalhães e seus escravos.

59 AFJM, Caixa Diversos 1875 a 1879, Apelação crime, 1875.
} 
vre" e, tentando mostrar que havia uma separação entre ser negro e ser cativo, Benedito acaba por afirmar que Umbelina era filha de escravos, informação que não tinha aparecido em nenhum momento do processo. As testemunhas são unânimes em dizer que Umbelina foi "xingada" de negra, cativa e que, tal qual escravo, se não se calasse, ela entraria no chicote.

Ao que parece, a imagem que Benedito tenta passar é que, mesmo biologicamente "negro", socialmente não o era, ou melhor, não queria ser, mesmo que fosse preciso recorrer aos hábitos dos senhores de escravos ao ameaçar "dar de chicote" em uma mulher "negra".

A defesa de Umbelina vem em sentido oposto à de Benedito, quando, em tom provocativo, ela diz: "sim, ela era negra, mas Benedito também era, [...] se sou puta é de meu marido e não dele e nem de outro dos Poções e que se ela era negra que não era dele". ${ }^{60} \mathrm{~A}$ primeira "denúncia" de Maria é de que todos estariam no mesmo "barco", isto é, todos eram negros. Umbelina se assume como negra e como uma mulher que vive em felicidade com seu marido. A defesa dela pode ser entendida à luz do que diz Bourdieu, que

o estigma produz a revolta contra o estigma, que começa pela reivindicação pública do estigma, constituído assim em emblema - segundo o paradigma black is beatiful - e que termina na institucionalização do grupo produzido (mais ou menos totalmente) pelos efeitos econômicos e sociais da estigmatização. ${ }^{61}$

No processo, diferentes dimensões da questão étnico-racial no Brasil se entrelaçam: racismo e identidade étnica. Tudo isso aparece em meio às diferentes representações sobre o que era ser negro naquela região e aponta para a complexidade do debate das relações étnicoraciais, que envolve racismo por um lado e - por que não dizer? identidade étnica por outro lado, e ajuda a entender as representações construídas na região sobre o ser negro e o "ser do negro". ${ }^{62}$

\footnotetext{
${ }^{60}$ AFJM, Caixa Diversos 1875 a 1879, Apelação crime, 1875.

${ }^{61}$ Ver Bourdieu, O poder simbólico, p. 125

${ }_{62}$ Parafraseando aqui Gislene Aparecida dos Santos, $A$ invenção do ser negro, São Paulo/Rio de Janeiro: Pallas/EDUC/Fapesp, 2002
} 
No cordel há uma questão de moral, de furto e também de racismo. Um "negro" que acusa outro de ter roubado, desqualificando-o socialmente e racialmente. Talvez o que Gabriel (filho de Benedito) implicitamente quisesse demonstrar é que nem todos os "negros" fazem isso, isto é, nem todos eram iguais. E se nem todos eram iguais, havia um lugar que começava a se construir como uma fronteira. Essa fronteira é de comportamento, mas se delimita também pelo saber escrever, ou seja, pela possibilidade de dialogar por meio de um "instrumento" tido como sendo de "branco", ou seja, a escrita personificada no cordel. As divisões, as tensões já vêm de muito tempo, por isso o "cordelista" escreve, pois está atento a toda a dinâmica social que o circunda. Ele está escrevendo e marcando aqui começa o "novo" (os padrões comportamentais a serem assumidos pelos negros, a cidadania a ser conferida), não em 1888, mas, ao menos em nossa pesquisa, já em 1875 .

\section{O "ser negro" e o "ser do negro": representações do negro por brancos.}

Em outra série de processos encontrados, o que estava em jogo eram também as diferentes representações sobre o "ser negro" e o "ser do negro", articuladas com outras dimensões da vida daqueles indivíduos. Entretanto essas representações eram feitas, sobretudo, pelos "brancos", não no sentido de cor de pele, mas construíam suas representações que partiam de uma ideologia do branqueamento que atravessava as fronteiras fenotípicas.

Em 1896, oito anos depois da abolição da escravatura, temos um processo que envolveu o pescador Tadeu, segundo uma das testemunhas:

[...] que estando ele (filho da testemunha) no rio mais Tadeu, jogando tarrafa quando chegou Ireno Dias de Cerqueira, pedindo peixe a Tadeu este respondeu que não tinha pegado e Ireno, vendo um saco com umas piabas e foi logo apanhando, Tadeu, disse a ele que deixasse minhas piabas, respondeu Ireno, não sei aonde [sic] estou que não te dou um tiro, negro. Respondeu Tadeu, pois atira, e logo imediatamente Ireno, atirou em Tadeu. ${ }^{63}$

${ }^{63}$ AFJM, Caixa Diversos, 1896, Auto de corpo de delito procedido contra Ireno Dias de Cerqueira, 1986. 
Apesar de não estar claro no processo, parece que já havia uma disputa anterior, que provavelmente não teria um cunho racial, entre Ireno e Tadeu e, no aumento das tensões, a questão racial emerge: “[...] não sei aonde [sic] estou que não te dou um tiro, negro". Tadeu não deixa a provocação sem resposta e diz: "então atira", o que resultou no seu ferimento.

Outra testemunha, José Marques dos Santos, de 37 anos de idade, lavrador e casado, ao descrever a mesma situação, não utiliza a palavra "negro", mas sim "nomes injuriosos".

[...] um filho dele testemunha, de idade de dez anos que estando o menino no rio mais Tadeu pescando no poço denominado da Pedra, Tadeu jogando tarrafa e quando chegou Ireno, pedindo pelo peixe que tinha pegado respondeu Tadeu, que não dava e ai Ireno, dirigiu-se a apanhar os peixes, e Tadeu, requereu a ele que não apanhase e ai Ireno pos a chingar [sic] nomes injuriosos os mesmos nomes Tadeu, respondera e no mesmo momento Ireno, deu-lhe um tiro em Tadeu. ${ }^{64}$

Anos depois, em 1897, uma história parecida com a de Tadeu se dá com Juviniano, que foi morto por Vicente com um tiro de garrucha na barriga. Segundo uma testemunha, depois de ter feito o disparo, "o Vicente Pintado, provocando em cima do cadáver do infeliz Juviniano de Tal, dizendo não te disse nêgo que eu te matava?". ${ }^{65}$

$\mathrm{Na}$ mesma forma do caso anteriormente analisado, o crime decorreu do aumento das tensões entre os dois por motivos que não ficaram claros para nós, mas, depois de praticado, eis que emerge, da voz de Vicente (por meio da fala das testemunhas), o racismo - "Não te disse nêgo que te matava?". Há todo um entrelaçamento entre a violência cotidiana e o racismo existente.

Essa situação parece se repetir em 1915, em um fato que envolveu José Urbano de Magalhães, o "José Pretinho, participante de um Terno de Reis e morador de José Gonçalves, atual distrito de Vitória da

\footnotetext{
${ }^{64}$ AFJM, Caixa Diversos, 1896, Auto de corpo de delito procedido contra Ireno Dias de Cerqueira, 1986.

65 AFJM, Caixa Diversos, 1896, Auto de corpo de delito procedido contra Ireno Dias de Cerqueira, 1986.
} 
Conquista. Descreve assim Bernardo Ribeiro de Menezes, 29 anos, solteiro e lavrador o que acontecera com José Pretinho: "eu respondente fechei a porta e fui para o interior da casa, pouco depois ouvi um tiro e em seguida muitos e ao terminar o tiroteio ouvi as vozes de Serafim, dizendo: conheceu negro como se atira em homem?"

O crime, aparentemente, foi em decorrência de uma disputa por questões de honra: um homem mais velho desafiou um mais novo e, levado pela euforia da bebida, o conflito se estabeleceu na manifestação da violência física. Entretanto, como a dimensão racial se fazia presente, com força explode, quando Serafim grita: "conheceu negro como se atira em homem?". O "preto" de José Pretinho, é esquecido; o que está em questão é o "negro", não como cor, mas, sobretudo como um lugar social, que entra na correlação de forças "homem mais novo" versus "homem mais velho", como uma variável que dava a esse homem "novo" e, segundo a fonte, branco, uma suposta superioridade frente ao homem "velho" e "negro". Isso pode ser também percebido na fala dessa mesma testemunha em outro depoimento dado um ano depois, em agosto de 1916, "ouviu o estampido de diversos tiros e palavras que ele testemunha conhecia visivelmente serem do denunciado que diziam, "conheceu negro, como é que moleque mata homem?"67

A questão da honra é associada à dimensão racial, como deixa claro outra testemunha, Francisco Graia, 27 anos, solteiro, lavrador:

Disse mais que ele testemunha sendo chamado por uma mulher, cujo nome não precisou, amazia [sic] de João Pretinho, para socorrer este, ancedeu [sic] e ai chegado ainda encontrou João Pretinho em ancia [sic] da morte e antes do lugar do crime o denunciado Serafim que the disse haver atirado no negro. ${ }^{68}$

O escrivão absorve a linguagem da testemunha, pois não fica claro no depoimento se teria sido a testemunha ou o escrivão que qualificara José Pretinho como negro, ou seja, quem de fato disse "haver atirado no negro", a testemunha, ou Serafim? ${ }^{69}$

\footnotetext{
${ }_{66}$ AFJM, Caixa Diversos 1890, Autuação 1916.

AFJM, Caixa Diversos 1890, Autuação 1916.

68 AFJM, Caixa Diversos 1911 a 1917, Autuação 1916.

${ }^{69}$ O processo termina quando, em 1917, Serafim é morto no distrito de São João do Alípio, distrito da região de Condeúba.
} 
Em 1922, encontramos a representação de Vicente Antônio da Silva, também "tocador de Reis", que fora ferido com uma facada no peito direito. Ele tinha 34 anos, era natural de Caculé e vivia na região de Vitória da Conquista, no lugar denominado Olho d'Água de Vital. A primeira representação de Vicente é feita pelos peritos, os "senhores doutores" Nicanor José Ferreira e Aparício Couto Moreira, e de natureza técnica: "Vicente Antônio da Silva, com trinta e quatro anos de idade, de cor preta". Na descrição "técnica", a racialização de Vicente.

As testemunhas tentam construir uma imagem de Vicente como alguém "metido a valente". Diz Eusébio Gonçalves Costa, 34 anos,

tendo o mesmo chegado de Itabuna [...] chegando teve que trazer um facão marca jacaré e uma pistola fogo central e dizendo que ele respondente que trouxe aquele facão para batizar no costado do pessoal do Pouso da Vaca. ${ }^{70}$

Essa imagem é reforçada por diferentes testemunhas, mas a dimensão racial do conflito também estava presente no depoimento de outra testemunha, Serapião Rodrigues dos Santos, 66 anos: "teve que saber por Geraldo Ribeiro de Queiroz acusado que Vicente achava-se ferido com uma facada no peito e tendo Geraldo dito para ele respondente que "nós matamos o negro"." 71

Dessa vez, o racismo não é evidenciado na hora da tensão, mas depois, quando os acusados relatam o que haviam feito. Isso também se dá com João Felix em 1927. No exame cadavérico realizado por Jovelino Rodrigues da Silva e João Queiroz de Brito encontramos a primeira descrição, em que a cor é logo ressaltada: "que examinando a pessoa de João Felix da Rocha, de cor preta, com vinte e oito anos de idade natural e residente deste distrito veste brim branco, camisa branca". ${ }^{72}$

$\mathrm{Na}$ fala de uma testemunha, percebe-se a naturalidade com que encara a violência e a definição dada pelo autor do tiro (Theodovico) sobre João Felix:

\footnotetext{
70 AFJM, Caixa Diversos 1924, Processo a requerimento do Sr Vicente Antonio da Silva contra os indivíduos Geraldo Ribeiro de Queiroz e Ponciano de Tal, 1922.

71 O processo não é concluído e é prescrito.

72 AFJM, Caixa Diversos 1927, Auto de corpo de delito, 1927.
} 
viajando em caminho ele Theodovico me disse que tinha atirado no João Felix, para que você fez isso! Ele não me respondeu mais nada viajemos a noite toda para a casa e não subemos da morte então no outro dia é que nós subemos que João Felix tinha morrido, mas Theodovico não falou que tinha atirado no negro João Felix com uma laproxe. ${ }^{73}$

Assim como no caso anteriormente analisado que envolveu José Pretinho, o escrivão "absorve" a linguagem da testemunha, pois não é explicitado quem dissera que João Felix era negro - a testemunha ou o acusado. Talvez isso aconteça por ser o qualificativo "negro", para pessoas como João Felix, um dado "natural" naquela realidade.

A briga se dera por uma questão material, uma dívida de seiscentos réis, mas a questão da cor estava ali, para os peritos e, indiretamente, para o próprio Theodovico. Nesse caso, podemos perceber certa diferença entre "preto" e "negro": para os peritos, João Felix era preto (cor), traço fenotípico, racializado; para as testemunhas (e Theodovico?), João Felix era negro (condição). Assim, o "preto" e o "negro" se misturam; preto como cor, e negro como condição.

De forma mais detalhada do que nos casos de Umbelina e Elias, em um processo de 1929, que envolve pessoas de Belo Campo, então distrito do município de Vitória da Conquista, é possível perceber, na fala de um advogado, que era viável mostrar a positividade desse "lugar", o "ser negro", e, nesse caso, o "ser africano". O processo é uma reivindicação de posse.

Um senhor de escravos (Antônio Ferraz de Araújo Catão) deixara, em testamento, uma fazenda para seus escravos com a prerrogativa de que eles acompanhassem sua esposa até a morte. Quando essa senhora se deslocou para Caetité, a terra dos libertos, fazenda Preguiça, depois denominada "São Domingos dos Negros" foi alugada por 24 anos. Ao morrer, o locatário colocou a fazenda como um bem para ser inventariado. Para resolver a questão, os ex-escravos entraram com uma ação ordinária de reivindicação de posse.

Diferentemente de outros processos, em que é possível perceber a fala da população afrodescendente, nesse, a que mais se destaca é a do

\footnotetext{
73 AFJM, Caixa Diversos 1927, Auto de corpo de delito, 1927.
} 
advogado Mário Monteiro de Almeida, brasileiro, casado, residente em Vitória da Conquista. Na primeira argumentação, ele ressalta a importância dos ex-escravos para Catão: "o Sr. Antonio Ferraz de Araújo Catão era homem de muitos e largos haveres, possuidor de abastados cabedais, ganho mercê de trabalho produtivo colaborado por inúmeros escravos". ${ }^{74}$

De acordo com o testamento de Catão, os ex-escravos deveriam servir a sua mulher até a sua morte e não poderiam vender a propriedade. Segundo o advogado isso foi cumprido:

Com uma dedicação irrepreensível e uma fidelidade só vulgar, no Brasil, na abundância de afetuosidade dos descendentes do generoso negro africano para aqui transplantado pela cobiça exagerada do europeu então mais que hoje incapaz da colonização pessoal das ricas terras sulamericanas, os legatários continuaram a servir a viúva do testador, seguindo-a resolutamente na sua peregrinação pela vida, rodeando-a sempre, sempre acompanhando-a, até os derradeiros momentos. ${ }^{75}$

Nas representações do advogado sobre o "generoso negro africano", é ressaltada a "afetuosidade" e feita a denúncia de que, para aqui, só viera por conta da "cobiça exagerada do europeu". A retórica utilizada pelo advogado mostra certa "positividade" do "ser negro" e do "ser africano".

O advogado de defesa é Themistocles Álvares Lima, que sempre aparece em processos analisados por mim em Ituaçu. ${ }^{76}$ Nele há outra visão sobre os "negros" que estavam fazendo a reivindicação de posse, eles habitavam "uns terrenos que se transformaram em verdadeiras capoeiras conhecidas geralmente pela denominação capoeiras dos negros".

O processo termina fora da justiça, quando o advogado dos exescravos pede que o processo seja suspenso, pois iriam fazer uma composição amigável. Se, de fato, houve essa composição, ela não passou

\footnotetext{
74 AFJM, Caixa Diversos 1929, Ação ordinária de reivindicação da fazenda "São Domingos" deste município e termo, 1929.

75 AFJM, Caixa Diversos 1929, Ação ordinária de reivindicação da fazenda "São Domingos" deste município e termo, 1929.

76 Uma discussão sobre a presença negra em Ituaçú e a atuação de Themístocles Álvares Lima pode ser encontrada em Washington Santos Nascimento, "Famílias escravas, libertos e a dinâmica da escravidão no sertão baiano (1876-1888)", Afro-Ásia, n. 35 (2007), pp. 220-40; e Washington Santos Nascimento, "Escravidão e memória: os negros no Arraial do Brejo Grande e na cidade de Ituaçu, Ba", Memória Conquistense, n. 7 (2007), pp. 19-38.
} 
pelas esferas judiciais, pois não localizei nenhum processo que fizesse referência a esse fato.

\section{Considerações finais}

Nas diferentes representações, percebo a racialização da sociedade na associação ao primeiro nome do indivíduo de um "apelido" que denota sua cor e origem. Vimos isso nos seguintes casos: Maria Crioula (1874), Inocêncio Crioulo (1889); Antônio Preto (1904); José Pretinho (1916); Vicente Preto (1922); Antônio Mulato (1924), entre outros. ${ }^{77}$ Ao discutir a "luta de classificações", Bourdieu diz que "a imposição de um nome reconhecido opera uma verdadeira transmutação da coisa nomeada que [...] torna-se uma função social, isto é, um mandato, uma missão, um encargo, um papel". ${ }^{78}$ Nesse sentido, o "apelido" representa um lugar social a não ser esquecido.

Mais do que uma "questão de cor", o que persistiu, mesmo depois da Abolição, foi o racismo articulado com um cotidiano "naturalmente" violento. À luz dos processos que analisamos, parece que o racismo era mais explícito com a população identificada como "preta". Em relação à população mestiça era mais sutil, mas, provavelmente, não menos perverso. Mesmo percebendo que havia uma diferença na representação entre "mestiços" e "negros", é preciso dizer, tal qual fez Consorte, que "a situação social dos mestiços, no entanto, mesmo que melhorada em relação à dos negros, estava longe, de alcançar os níveis atingidos pelos brancos, em seu conjunto, encontrando-se muito mais próxima daqueles". ${ }^{79}$

Os "apelidos" evidenciam o que também percebi ao longo da pesquisa: não importam os graus de mestiçagem, o lugar social era de negro. Tratava-se de um lugar social em movimento; "lugares", principalmente quando percebemos que havia negros que se consideravam menos negros do que outros, e que isso não resultava necessariamente da cor da pele, mas do estabelecimento de fronteiras sociais. Apesar das

\footnotetext{
77 Não encontrei no período estudado, mas levando em consideração alguns apelidos ainda existentes na cidade de Vitória da Conquista, talvez houvesse também apelidos como "branco", "claro" etc.

78 Bourdieu, $A$ distinção, p. 444.

79 Ver Consorte, A mestiçagem no Brasil, p. 110-1.
} 
evidências empíricas não serem conclusivas, acreditamos que esse negros, que conseguiram algum grau de ascensão social, eram influenciados pela ideologia do branqueamento, construindo dessa forma parâmetros comportamentais e civilizatórios, ligados ao mundo branco europeu.

Nas representações, os lugares aparecem associados ora à resposta a valores dominantes na sociedade, como os bons modos e a civilidade, ora à afirmação de valores de origem africana, ou seja, como "contra-lugares" construídos a partir da negação do primeiro. Umbelina, Elias e o argumento de defesa feito pelo advogado Mário de Almeida, são exemplos de que era possível ocupar um "lugar social" ligado à "turbulência" e à "falta de civilidade" e nele construir "contra-lugares", ou seja, construir "identidades de resistência", o negro, ou seus interlocutores, assumindo a sua negritude e/ou africanidade e construindo uma resistência a partir dela.

Todos os personagens descritos até aqui, negros e/ou mestiços, estavam em determinados lugares que eram entrecortados por diferentes representações, ou seja, um mesmo personagem poderia ocupar mais de um desses lugares, às vezes, em uma mesma situação.

Como se vê os lugares do negro construídos até agora a partir de representações formadas segundo a ideologia do branqueamento (mesmo difusa e não sistematizada) não são estáticos, estão sempre em construção, tanto pela imposição de determinados modelos como pela negação, resistência e desconstrução desses mesmos modelos.

Pairando sobre todas essas representações, como um pano de fundo, um desejo de civilidade e progresso para a região e para o país, existe, por parte dessa sociedade conquistense, a constatação da diversidade de sua população e de que, em uma sociedade com um profundo grau de mestiçagem e com uma grande quantidade de negros, a "civilidade" é fundamental para a construção de uma cidade, naquele momento, ainda retórica, não-real.

Por fim, cumpre destacar que, não obstante a mestiçagem, o racismo sempre esteve presente entre nós. Não importam também as diferentes tonalidades de pele, o lugar social é de negro, e quando esse lugar veio associado à condição de pobreza e de mulher a vida não foi generosa com esses personagens, mas como evidenciam de maneira mais clara alguns processos, eles estavam longe de serem vítimas indefesas. 


\title{
Anexo A
}

Cordel na íntegra feito por Gabriel, no Arraial dos Poções (1875).*

\author{
Senhores eu estou pronto \\ Venham prestar atenção \\ Um causo que aconteceu \\ Com Maria de Latão
}

Senhores dão licença

Que quero explicar

Depois que Deolino morreu

Olha Maria como está

Muito dos senhores

Não conhece Maria

Mora na rua de baixo

Bem na beira do caminho

O pai na rua de cima Olhando para o padrim

A filha na rua de cima

Roubando o Raimundim

Torta como Umbelina

Nem tão cego como Latão

Nem tão ladra como Maria

Que furta até no balcão

A Maria de doze anáguas

Bastante serpentina

Latão tão bem pinta

Negocio bem a surdina

Maria de doze anáguas

Para influencia do mundo

Mais quem estava sofrendo

Era a casa de Raimundo

Fonte: AFJM, Caixa Diversos 1875 a 1879, Apelação crime, 1875. 
Logo naquele dia

[...] Latão foi delegado

Raimundo tomou de Maria

Trinta mil reis furtado

Este é o que me consta

Quando foi o que ele tomou

Julgava ser gente da casa

E Maria foi quem furtou

Raimundo não sabia

Do roubo que ele sofria

[...]

Dele vender a negra Sufia

A mulher se apegou

Com os santos de sua devoção

Que ele lhe mostrasse

Quem era este ladrão

Falou esta palavra

Com dor no coração

De mandar dizer uma missa

E o ver com os pés no chão

Logo no outro dia

Em cima do balcão

Raimundo chamou Maria

Venha ver o ladrão

Ficou ela muito contente

Em com bastante alegria

Perguntando quem era o ladrão

Ele disse que era Maria

Ela se desanimou

Não me diga isso não

A Maria que furtou

Foi Maria de Latão

Latão disse que não vinha

Mais nesta rua de cima

Porque cá só tinha ladrão

E porção de assassinos. 
Como ele agora está

Querendo ser cidadão

Falando da rua de cima

E lá mesmo é que tem ladrão

Raimundo mais que depressa

Amarra a negra Sofia

Indo com ela na corda

Ela bateu na porta de Maria

Raimundo na ponta da corda

Vendo o que a negra dizia

Ela bateu na porta

Mim dá o dinheiro Maria

Raimundo foi enxergando

Com muita alegria

Maria foi intregando

Todo o dinheiro que tinha

Ele foi arrecebendo

$\mathrm{O}$ dinheiro com as mão

Foi logo dizendo

Já sei quem é o ladrão

Alegre que ele ficou

Prejuízo que sofria

Disse ela em voz baixa

Você é uma ladra Maria

Ele chamou Latão

Assim que amanheceu o dia

Que estava roubado

Por Sofia e Maria

Raimundo estava falando

João Chaves disse que não

A negra tinha ido ver

Era um par de butão

A negra bateu na porta

Isto é muito certo

Maria de quem é os butão

São de Felisberto. 
Raimundo disse mesmo

Que ainda tinha redevu

Que tem uma nopretissa (?)

E lá tem uns baús

O Latão com estas fala

Foi ficando cheio de angustia

Raimundo falou com Puluca

[...] mandado de busca

[...]

Por influência do mundo

Arretirou os baús

Franqeou a casa Raimundo

Raimundo requer busca

Pois falou com Puluca

Diga a Latão e a Maria

Que o ladrão e a mulher de Juca

Foi logo naqueles dias

Que veio [...] João

Quando faltava qualquer coisa

Raimundo chamava Latão

Venha cá Latão

Venha ver o que me faltou

Olha que tudo isto

E Maria que furtou

Latão baixava a cabeça

Com a cara no chão

É bem feito para o torto

Chame agora os outros ladrão

No dia que João Chaves

Casou as duas filhas

Maria deu vinte mil reis

Para comprar duas novilhas

Latão para falar dos outros

Juro que infara

Mais ninguém cuspa para cima

Que não lhe caia na cara 
Amancio bate sentido

Não se fie em todo mundo

Olha Maria que não te faça

O que ela fez a Raimundo

Já me despeço

A Deus que me arrretiro

Até quando cá tornar

Será breve a minha vinda

Se Maria não se incomodar

Voz do povo

Quem não quer ser pele

Não vista o lobo

Texto recebido em 23 de janeiro de 2009 e aprovado em 10 de agosto de 2012

\section{Resumo}

Esse artigo tem por propósito discutir acerca das representações construídas sobre a população afro-descendente (mestiços, pretos, negros) por diferentes atores da realidade do sertão baiano, entre os anos de 1870 a 1930, particularmente na região de Vitória da Conquista, sudoeste do Estado da Bahia. As fontes que utilizo são, sobretudo, jornais e processos crimes, por se tratar de documentos que possibilitam adentrar no universo cotidiano da população mais pobre.

Palavras-chaves: representações sociais - afro-descendentes - sertão baiano

\section{Abstract}

This article intends to discuss the constructed representations of the population of African descent (mestizos and blacks) by different actors in the reality of the backlands, between the years 1870 to 1930, particularly in the region of Vitoria da Conquista, in the southwest of the state of Bahia. The sources used are, above all, newspapers and crimes cases, as it is possible that such documents facilitate entrance into the everyday world of the poorer population.

Keywords: social representations - african-descendants - backlands Bahia 